\title{
El emblema de Navarra
}

\author{
José María Muruzábal Aguirre *
}

\section{LA EDAD MEDIA}

El doctor Faustino Menéndez Pidal explicó en su artículo Sellos, signos y emblemas de los reyes de Navarra, desde el Restaurador a los Teobaldos ${ }^{1}$ cómo el primer emblema heráldico de Navarra fue el "águila negra", que vemos en el reverso de los sellos de Sancho VII el Fuerte ${ }^{2}$, en diversos monumentos de inicios del siglo xIII, claves de bóveda de algunas construcciones $^{3}$, y finalmente en los sepulcros de las Huelgas correspondientes a la madre y hermano de Sancho VII ${ }^{4}$.

Por otra parte, el P. Moret ${ }^{5}$, en sus Investigaciones históricas de las antigüedades del Reino de Navarra, se muestra partidario de aceptar como blasón de Navarra el escudo con las cadenas arrebatadas por Sancho VII el Fuerte al Miramamolín ${ }^{6}$ en la batalla de Las Navas de Tolosa (1212). Atribuye a este rey un sello ${ }^{7}$ con la representación de las pretendidas cadenas en figuras ecuestres. Pero éste es un sello con representaciones ecuestres en el anverso y en el reverso y constituye un tipo sigilar anterior a los sellos con imágenes heráldicas de representación territorial o "sellos de señal». Una de estas imágenes territoriales ya tenía Sancho el Fuerte

* Ldo. Historia del Arte.

Menéndez Pidal de Navascués, F., Sellos, signos y emblemas de los reyes de Navarra, desde el Restaurador a los Teobaldos, "Príncipe de Viana", Primer Congreso General de Historia de Navarra. 3 Comunicaciones. Edad Media. Pamplona 1988, págs. 105-106.

2 Años 1214 y 1225 . Es típico del momento la utilización de una señal emblemática en el reverso sigilar.

3 Monasterio de Oliva, templo de fines de siglo XIII, y la Iglesia-fortaleza de Ujué, que tiene una bóveda de inicios del siglo xIv, pero con una clave de factura muy anterior.

- Se trata de dos sepulcros conservados en el pórtico del monasterio de las Huelgas de Burgos. Ambos tienen en sus costados ocho escudos con águilas, leones y blocas.

5 José Moret y Mendi (1615-1687).

- Se trata del Califa almohade, emir almuminín, Abú Abd Allah Muhammad Ben Yagub Ben Yusuf An Nasir.

7 Es un sello que se pende de una carta guardada en el archivo de la catedral de Tudela y actualmente está en el archivo general de Navarra (AGN, pergaminos de Tudela, $n .{ }^{\circ} 7$ ). 
y era su "águila negra» que probablemente se usó desde el inicio de su reinado. Por tanto, las barras radiales aparecen en sellos anteriores a 1212, fecha de la batalla de Las Navas de Tolosa. Y también en relieves anteriores a tal fecha, tanto en Navarra como fuera de ella. Hasta en el Poema del Mío Cid y en la Chanson de Roland se habla de escudos blocados ${ }^{8}$. La bloca era la prominencia central de un escudo, normalmente bien ornamentada, pero que ante todo constituía el centro de donde partían los refuerzos metálicos del escudo; barras, dispuestas radialmente, y que acabarán llamándose como su centro, bloca. Por tanto, el sello que el P. Moret atribuyó a Sancho el Fuerte fue en realidad de Sancho el Sabio, aunque pudo haberlo utilizado su sucesor. Se equivocó el insigne cronista del Reino de Navarra, José Moret, y acierta el doctor F. Menéndez Pidal en sus explicaciones.

$Y$ si interesa descubrir el origen remoto del escudo de ocho radios, también conviene buscar una explicación a la presencia del «águila negra». Para F. Menéndez Pidal, la clave debe encontrarse en las franjas blancas que tiene en la cola, en el cuello y en los bordes de las alas. Pero después afirma que debe relacionarse con la villa de L'Aigle, feudo familiar de la reina Margarita, sobrina del Conde Rotrou y de Alfonso el Batallador, y esposa de García Ramírez el Restaurador. Margarita aportó Tudela a la monarquía navarra, pues era tenencia de su tío; y García Ramírez, tanto por su matrimonio como por su ascendencia - nieto del Cid y de un Infante de Navarra - tenía amplios apoyos para ostentar la realeza. Finalmente, F. Menéndez Pidal cree que Sancho el Sabio (11501194) debió ostentar algún signo, quizá el águila, junto a otros personajes que participaron en la gran parada organizada por Alfonso VII en 1154 en Toledo.

Puede observarse cierta contradicción en las ideas del doctor F. Menéndez Pidal, pues la presencia del águila se explica como una referencia al Condado de L'Aigle para después buscar su origen en las misteriosas franjas blancas. ¿Cuál de los dos criterios será el adecuado?

En primer lugar he de decir que nada de extraño tienen las franjas blancas del águila. Si existe el detalle naturalista de representar mediante un círculo blanco el ojo del águila, tampoco hay que despreciar las manchas blancas del plumaje. Las águilas son aves de color oscuro parduzco, pero con zonas blancas o franjas claras en diversas partes del cuerpo.

8 Veamos algunos ejemplos: “Al cuello llevan los escudos con centros de oro...", "...Rompe y arranca la broca escudo del enemigo...". "Entonces Nuño Gústioz carga a su vez, quiebra el escudo por la broca...". 
Así, las águilas real, imperial, pescadora y otras tienen manchas y listas aclaradas en las zonas antedichas, y no podían representarse en un dibujo a tinta sino con huecos blancos entre los trazos negros. No es aquí donde hay que buscar el origen del "águila negra».

La referencia al condado de L'Aigle creo que también es criticable. Molesto tenía que resultar para un rey hacerse representar él o su reino por un signo condal, de procedencia materna y propio de una villa poco importante. Más aún si ha de estar, como dice F. Menéndez Pidal, en compañía y competencia de otros signos en una parada militar. Pudo tener alguna motivación familiar el "águila negra», pero, desde luego, el trabajo de buscar el origen de tal emblema no es complicado ni laberíntico. El águila es una referencia y símbolo universal; una imagen bien enraizada en la conciencia y la cultura popular. La Mitología, la Historiografía, la Historia del Arte y Numismática, y finalmente la Biblia, están llenas de alusiones al águila como ejemplo de majestad, de poderío y superioridad, y finalmente de protección divina y providencia.

Para los griegos, el águila era la reina de las aves. Dispensadora de fertilidad y dicha, fue también mensajera de Zeus. Afirma San Isidoro en sus Etimologías, tan importantes en la Historiografía de Navarra, que el águila proporcionó a Júpiter auspicios favorables cuando iba a enfrentarse con los Titanes. La aparición de una de ellas fue interpretada como augurio de victoria y Júpiter la adoptó como protectora y se la concedió como enseña a las legiones. Los griegos y romanos plasmaron la imagen del águila en multitud de esculturas y relieves, en templos, aras y monedas. Está presente en la orfebrería del arte visigodo y merovingio, y, como era de esperar, la utilizaron los artistas de la época carolingia. Pero donde aparece con mayor rotundidad y elevación es en la Biblia. Aparece aquí como imagen y ejemplo de la providencia de Dios y de su acción protectora sobre su pueblo ${ }^{9}$. También es el águila bíblica un símbolo del poder de Dios y de su señorío absoluto sobre los acontecimientos de la Historia. En el Salmo 103 es presentada el águila como ejemplo de ju-

9 Ex. 19,4: «Vosotros habéis visto lo que yo he hecho a Egipto y cómo os he llevado sobre las alas del águila y os he traído hacia Mí. Ahora, si oís mi voz y guardáis mi alianza, vosotros seréis mi propiedad entre todos los pueblos de la tierra".

Dt. 32,10-11: "Le rodeó y le enseñó. Le guardó como a la niña de sus ojos. Como el águila que incita a su nidada, revolotea sobre sus polluelos. Así El extendió sus alas y los acogió. Y los llevó sobre sus plumas. Sólo Yavé le guiaba. No esta con Él ningún Dios ajeno".

Sal. 17,8: "Guárdame como a las niñas de tus ojos, escóndeme bajo la sombra de tus alas".

Sal. 91,3-4: «Pues Él te librará de la red del cazador y de la peste exterminadora. Te cubrirá con sus plumas, hallarás seguro bajo sus alas y su fidelidad te será escudo y adarga".

Is. 31,5: "Como aves que levantan el vuelo protegerá Yavé de los ejércitos a Jerusalem". 

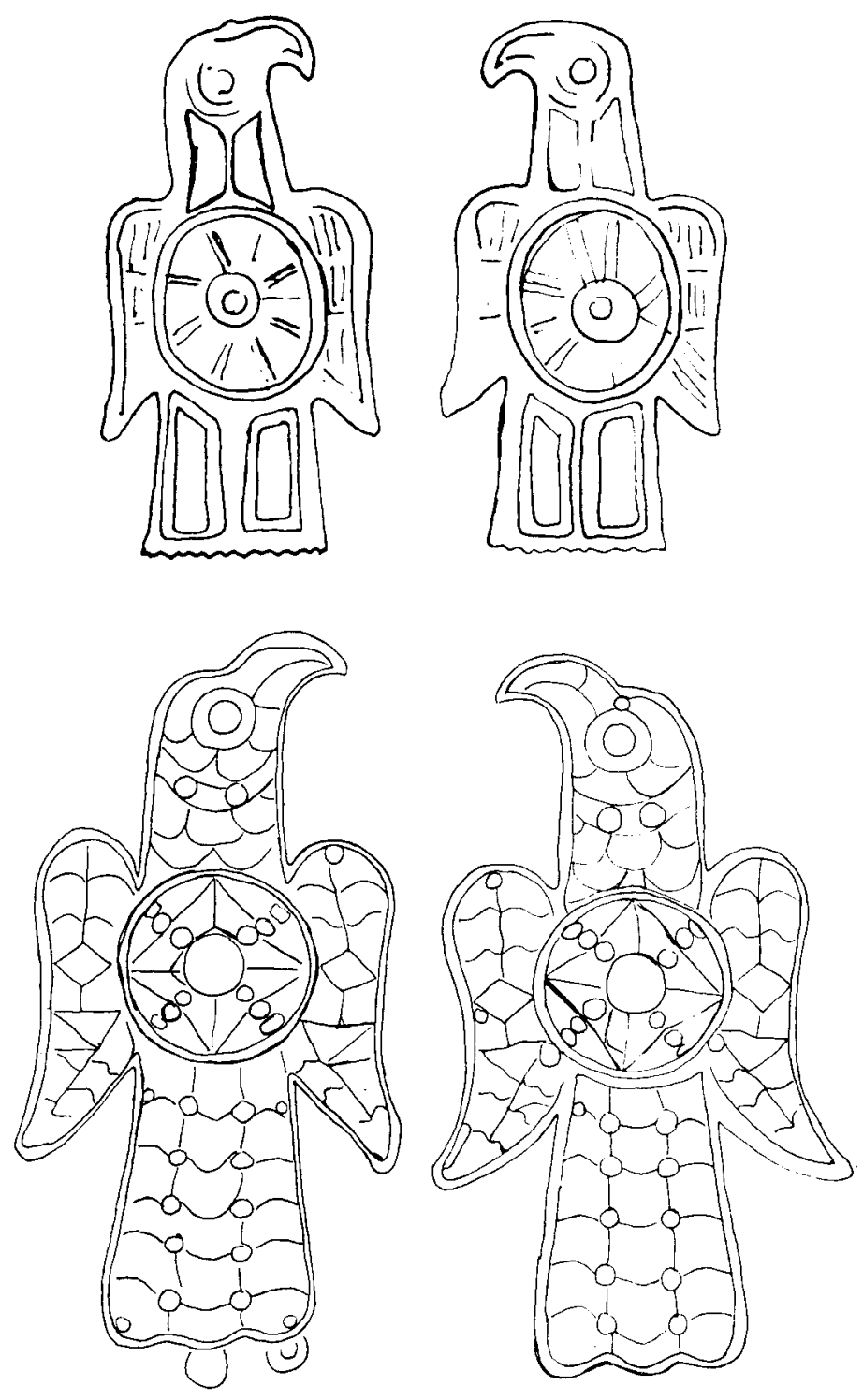

Fig. 1. Águilas emblemáticas. Águilas visigodas. 
ventud y vitalidad: "Bendice, alma mía a Yavé y bendiga todo mi ser su santo nombre. (...). Él rescata tu vida del sepulcro y te corona de piedad y misericordia. Él sacia de bienes tus deseos y renueva tu juventud como la del águila ". De manera parecida proclama Isaías: “... pero los que confían en Yavé remuevan las fuerzas, echan alas como de águila, corren sin cansarse y caminan sin fatigarse". (Is. 40,31). La iconografía antigua representó a los cuatro evangelistas con las imágenes de cuatro vivientes alados de la corte celestial y de diferente aspecto: de hombre, de toro, de león y de águila. En antiguos textos bíblicos, como los famosos Apocalipsis de Beato, podemos ver representaciones de águilas semejantes a las que tratamos aquí.

Muchas son las alusiones bíblicas del águila: águila protectora y símbolo de la inspiración divina, águila guerrera y victoriosa, apropiado modelo y guía para el atribulado reino de Navarra, tan acosado por musulmanes y por cristianos. Creo que el águila de Navarra es ante todo una referencia bíblica, como también lo es el debatido árbol de Sobrarbe.

$\mathrm{Ya}$ el P. Moret, en sus Investigaciones... afirma que no hay pruebas que acrediten la veracidad de la leyenda sobre el árbol crucífero o árbol de Sobrarbe ${ }^{10}$. Argumenta también que no hay ejemplos de tal emblema en ningún documento o monumento, fuera de las monedas; $y$, finalmente, que en ninguna de ellas aparece la inscripción Sobrarbe y sí Navarra o Aragón. Señala Moret que tal vara o asta no tiene la copa y ramajes propios de un árbol y que crecen de forma inusual dos pretendidas ramas, pues nace en casi todos los casos del pie de árbol. Cree Moret que son lazos ornamentales y afirma que la calificación de àrbol se debe a que estos lazos tienen una apariencia ramificada. El P. Germán de Pamplona ${ }^{11}$, también rechazó la interpretación del árbol crucífero como árbol de Sobrarbe en su artículo Discutibles interpretaciones de la moneda de Sancho el Mayor ${ }^{12}$.

F. Mateu y Llopis, gran estudioso de la numismática española, aporta en una de sus obras ${ }^{13}$ nuevas luces al tema. En primer lugar, atribuye al árbol crucífero la designación "arbor ad modum floris" o árbol a modo de flor. Presenta un documento de 1247 que así lo hace ${ }^{14}$, y reconoce

\footnotetext{
10 Aparición milagrosa de una cruz sobre un árbol, al rey García Ximénez.

1 (1899-1977). Sacerdote capuchino, doctor en Filosofía y Letras y autor de diversos trabajos de Historia.

12 Revista internacional de estudios vascos, 1925, t.XXVI, págs. 655-660.

13 MATEU Y Llopis, $F$., "El arbor ad modum floris en dineros de Cataluña, Navarra, Aragón y Valencia». Siglos $x$ al XIII, Príncipe de Viana, 30, N. ${ }^{\circ} 116-117$. Pamplona 1969, págs. 245-254.

${ }^{14}$ "...sit caput regium coronatum et in relinqua parte sit arbor ad modum floris, in cuius summitate extensa usque ad superiorem circulum, ponatur Crux contigua ipsi arbori, infra extremum circulum».
} 
$=\because$ Z:

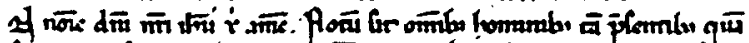

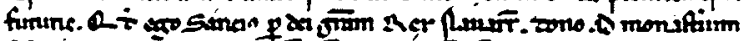

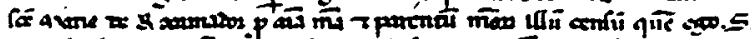

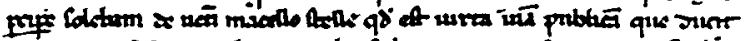

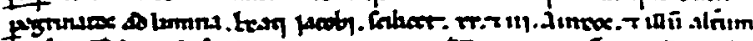

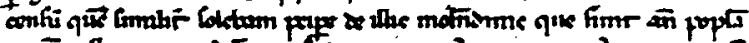

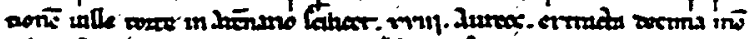

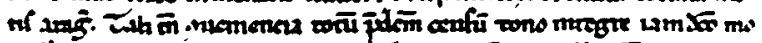

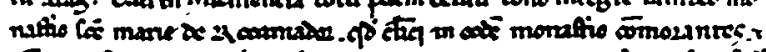

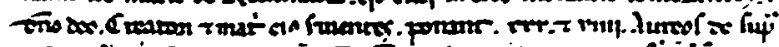

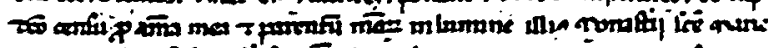

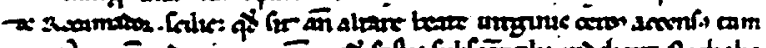

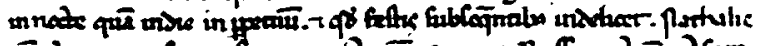

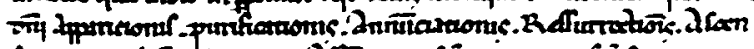

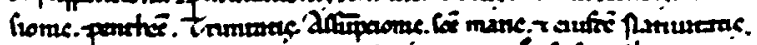

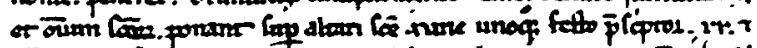

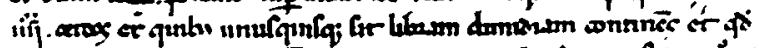

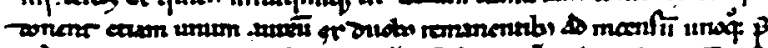

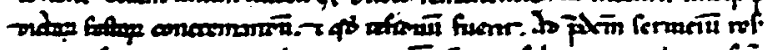

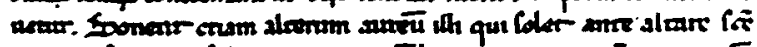

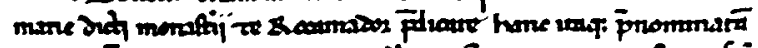

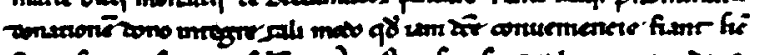

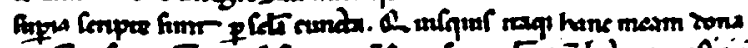

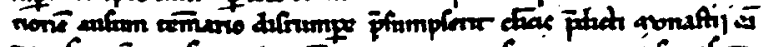

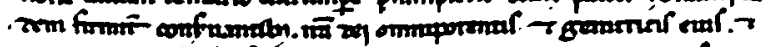

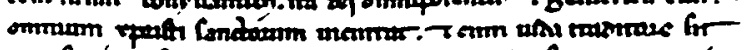

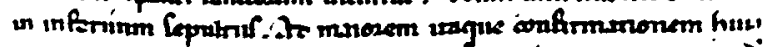

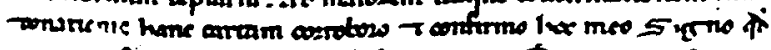
fablequat mes pous minu fucte.

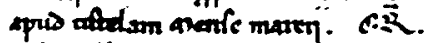

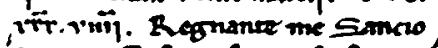

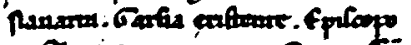

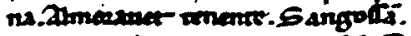

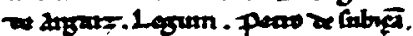

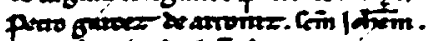

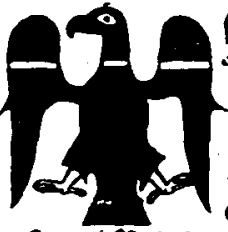
forta curr

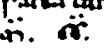
Hoge on i parmpik Radrio Tisham Tonolus

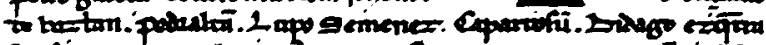

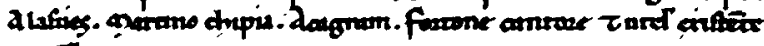
ancilimo.
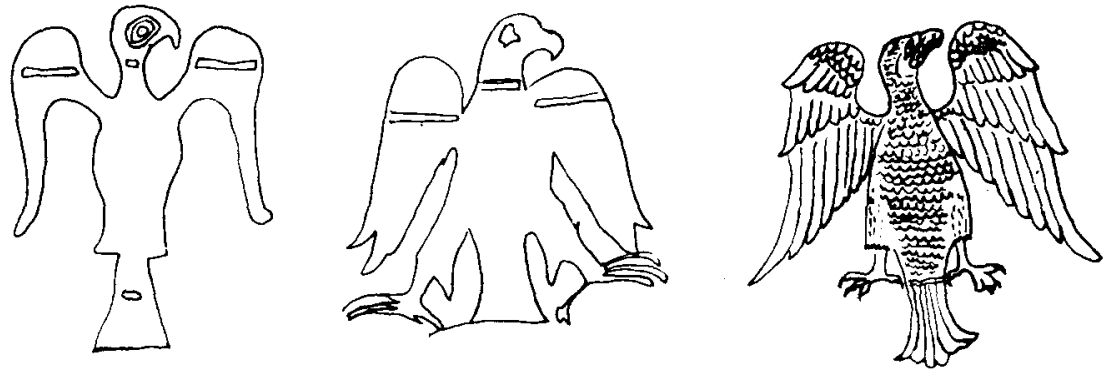

Fig. 2. Águilas de Navarra. 
la mayor antigüedad de las monedas catalanas con árbol crucífero sobre las navarras. Ya lo encontramos con Ramón Borrell (992-1018). La primera moneda navarra con este árbol la atribuye Mateu y Llopis a Sancho el Mayor (1000-1035), y advierte su presencia en las monedas de Aragón como Sancho Ramírez (1063-1094), como también aparecerá en Valencia en tiempos de Jaime el Conquistador (1213-1276). Pero los tipos numismáticos se difunden fácilmente, pues hay monedas del rey de Dinamarca e Inglaterra, Canuto el Grande (994-1014-1035), que también tienen el árbol crucífero. El problema estriba en que nadie da una explicación creíble a este misterioso árbol.

Su imagen es sorprendente. Se trata de una larga vara con una cruz en su extremo superior. De los lados salen dos ramas claramente festoneadas, pero pueden hacerlo desde casi la base del árbol, hasta nacer cerca de la cúspide. Lo importante, por lo que se ve, es que la vara sea rígida y vertical, y que la cruz repose sobre ella y por encima de las ramas y hojas. No he encontrado en las fuentes visigodas, en la latinas, o en la literatura eclesiástica ${ }^{15}$ ningún texto que se adapte al diseño del árbol crucífero. Pero si lo hace un maravilloso pasaje de la Biblia. En el capítulo 11 del libro de Isaías hay un texto singular:

"Y brotará un retoño del tronco de Jesé y retoñará de sus raices un vástago. Sobre el que reposará el Espíritu de Yavé, espíritu de sabiduría y de inteligencia, espiritu de consejo y de fortaleza, espíritu de entendimiento y de temor de Yavé.

Y su respirar será en el temor de Yavé. No juzgará por vista de ojos ni argüirá por oídas de oídos, sino que juzgará en justicia al pobre y en equidad a los humildes de la tierra. Y herirá al tirano con la vara de su boca, y con el soplo de sus labios matará al impío. La justicia será el cinturón de sus lomos, y la fidelidad el ceñidor de su cintura.

Habitará el lobo con el cordero, y el leopardo se acostará con el cordero, y comerán juntos el becerrro con el león, y un niño pequeño los pastoreará. La vaca pacerá con la osa, y las crías de ambas pacerán juntas; y el león, como el buey, comerá paja. El recién nacido jugará junto a la hura del áspid, y meterá la mano en la caverna del basilisco. No habrá ya más daño ni destrucción en todo mi monte santo, porque estarála tierra llena del conocimiento de Yavé, como llenar las aguas del mar.

En aquel día, el renuevo de la raíz de Jesé se alzará como estandarte para los pueblos, y le buscarán las gentes, y será gloriosa su morada.

En aquel día, de nuevo la mano del Señor redimirá al resto del pueblo, a lo que resta de Asur y de Egipto, de Patros, de Cus, de Elam, De

15 Patrologia latina, Patrología griega, Corpus christianorum.. 
Senaar, de Jamat y de las islas del mar. Alzará su estandarte en las naciones, y reunirá a los dispersos de Israel, y juntará a los dispersos de Juda de los cuatro confines de la tierra. Y cesará la envidia de Efraím, y serán destruidos los enemigos de Judá, y Judá no será más enemigo de Efraím.

Y se alzarán contra la costa de los filisteos a Occidente, y juntos saquearán a los hijos de Oriente; Edom y Moab les servirán, y los hijos de Ammón les estarán sujetos. Y secará Yavé la lengua del mar de Egipto, y levantará su mano sobre el río, con el terror de su soplo, y herirá sus siete brazos, que podrán pasarse a seco.

Y abrirá camino a los restos de su pueblo, allos que quedarán de Asur, como los abrió para Israel el día de su salida de Egipto".

Veamos cómo es la versión latina del inicio de este texto: "Etreditur virga de radice lese et flos de radice eius ascendet». El término "radice" puede significar simplemente las raíces de un árbol, pero también el origen o fundamento de algo. Así, «radix» es el pie o falda de un monte, o también puede traducirse como el tronco de un árbol, que es base para ulteriores ramificaciones. Se puede, pues, traducir como tronco o como raíces. El término «virga» puede interpretarse como rama o vara, o también como retoño. Del tronco o de las raíces de Jesé nacerá, nos dice el texto, una vara o un retoño. Naturalmente, el término "flos" equivale a flor. Se trata del libro de Emmanuel, una bella profecía del nacimiento de Cristo.

Todos los datos del texto coinciden con las características del árbol crucífero: un árbol con un tranco bien destacado y unas ramas que salen de él a modo de complemento. Puede entenderse que del árbol de Jesé nace un retoño o una flor, y que en la imagen está sustituida por una cruz, pues la flor de Jesé es Jesucristo. También puede entenderse en el texto bíblico que una vástago surge del tronco de Jesé, que es Cristo, y la cruz queda fundida a dicha vara interpretándola y dándole su sentido exacto. Finalmente cabe traducir radix como raíz, y entonces todo el conjunto de árbol, vara y flor surge de las raíces de Jesé, y por ello en muchos grabados las ramas del árbol nacen de la misma base del tronco. Pero es difícil imaginar y representar una flor o una simple vara surgiendo imprevisiblemente del tronco de un árbol, o de sus raíces. Por eso cabe una cuarta interpretación conjunta en donde una vara y una flor nacen del tronco y raíces de un árbol. Es significativo, como dice el P. Moret, que el árbol no tenga copa, o al menos varias ramas, en su parte superior; pero aunque es un árbol singular, especial, distinto a los demás, lo es auténticamente. Existen algunas otras citas bíblicas que representan como una flor o un retoño a Jesucristo y al pueblo judío, su lejana imagen. Veamos algunas: Sal. 78,31: «...cuando montó en cólera Dios contra ellos, e hirió de muerte a los robustos y abatió a la flor de Israel». Jer. 33,15: 
"En esos días y en ese tiempo, yo suscitaré a David un renuevo de justicia que hará derecho y justicia sobre la tierra". Ap. 5,5: "No llores, mira que ha vencido el león de la tribu de Judá, la raíz de David, el lucero radiante de alba».

El origen del emblema del árbol de Jesé es muy anterior a los tiempos del reino de Navarra. Concretamente, es el arte visigodo el que contiene una notable gama de imágenes de flores, arbustos -a veces semejantes al árbol crucífero-, y hasta flores de lis, que pueden identificarse con el árbol de Jesé, la flor de Jesé. Se encuentan esculpidos en paredes, frisos, tableros, pilastras... Igualmente aparecen en las monedas flores de lis y cruces sobre troncos, o fundidas a ellos. Este emblema no sólo se extiende durante la reconquista, sino que pasa a Francia. Lo encontramos tanto en las monedas merovingias como en las carolingias. Entre las primeras hay elementos vegetales y tallos con flores de lis que pueden explicarse, creo, como representaciones del árbol de Jesé. También las monedas carolingias ${ }^{16}$ tienen algunas flores de lis; $y$ pienso que la llamada "crois ancrée" o cruz anclada, que hay en algunas piezas numismáticas, no es sino la cruz del símbolo de la omega. Castaing Sicard estudia las monedas feudales del Languedoc - siglos $x$ al $x I I-y$ presenta en sus láminas abundantes ejemplos vegetales y florales. Pero los interpreta mal, ceo, pues sólo ve ornatos vegetales y tallos separadores en lo que, pienso, son emblemas de Jesé, y hasta califica como asterisco y "croissant" to que es evidentemente una estrella y una luna, y cuyo significado veremos más adelante. Posteriormente, estas imágenes del árbol y flor de Jesé darán lugar a la general aceptación de la flor de lis, la cual será el emblema de los reyes de Francia. No se debe su presencia a los pantanos donde surgió y vivió el pueblo franco y en cuya tierra brotaban espontáneamente lirios. Tampoco a las coronas de lises que los soldados de Clodoveo tejieron tras vencer en Tolviac, según dice la leyenda. Igualmente extraño es ver un cetro con una punta de lanza, como se ha creído ver en un sello del rey Lotario publicado por Mabillón, puesto que tal instrumento es un símbolo de autoridad real y no un emblema guerrero. Más bien estas leyendas surgen tardíamente, al olvidarse el primitivo sentido de la flor de Jesé. La flor de lis es la vara y retoño de Jesé. Jesucristo es la flor de lis.

El texto bíblico se refiere a una flor indeterminada, genérica, pero con el tiempo pudo ser reputada como un lirio, el lis francés, pues éste es

16 Prou, M., Les monnaies carolingiennes. Gratz 1969. Prou, M., Les monnaies merovingiennes. Gratz 1969. 

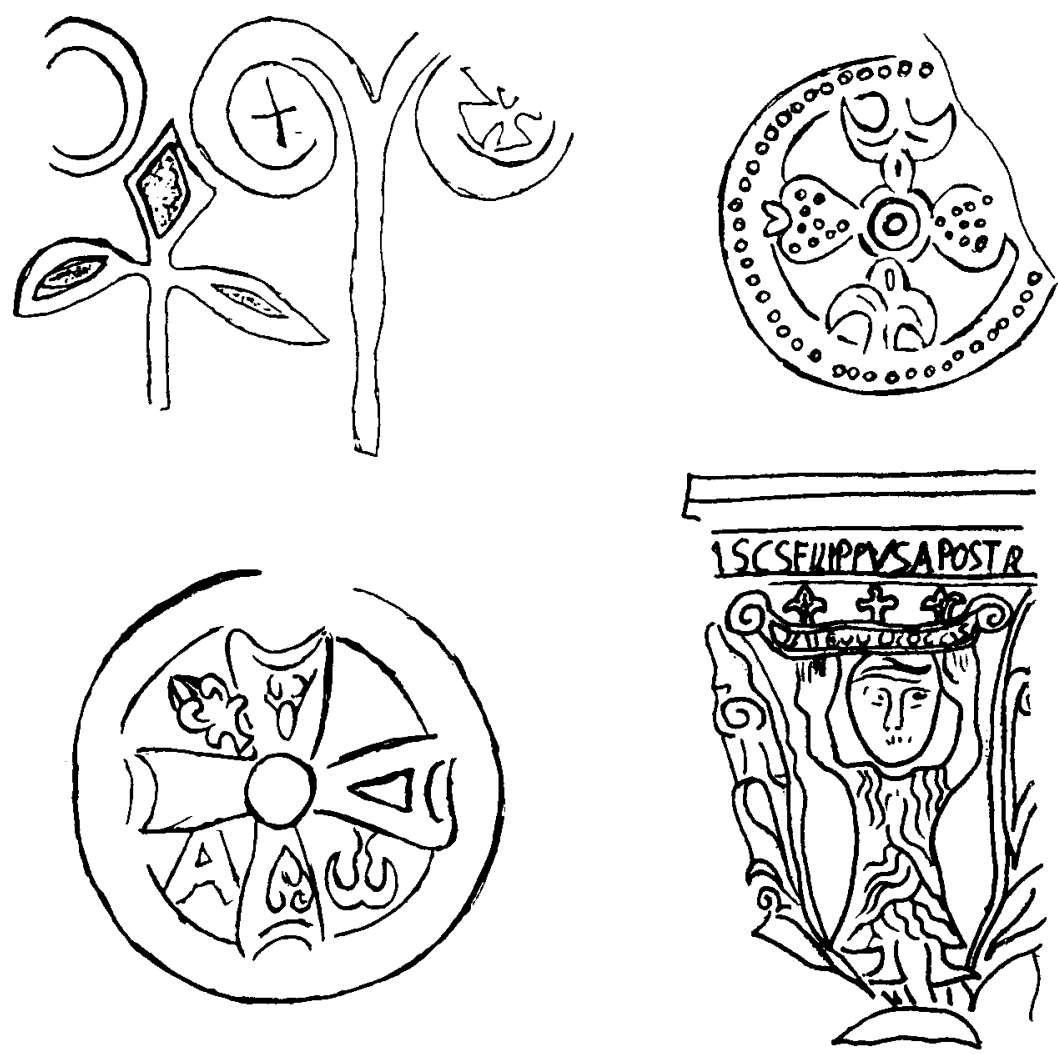

Fig. 3. El árbol de Jesé y la flor de Lis (arte visigodo).

una flor bíblica que aparece frecuentemente en las Sagradas Escrituras, y no es estraño que se le diese tal carácter a la flor de la monarquía franca ${ }^{17}$.

En la Edad Media se creía que además de un solo Papa para toda la cristiandad, debía de haber también un solo emperador o por lo menos un solo imperio y una sola "universidad christiana". Esto se debía a las

17 Ex. 25,31-34: Harás un candelabro de oro puro, todo lo harás de oro puro, de oro bat: ${ }^{-3} 2$. con su base, su talio, sus cálices, sus globos y sus lirios saliendo de él. Seis brazos saidrán de sus lados, tres del uno y tres del otro. Tres cálices a modo de flores de almendro, tendrán el primer brazo, con sus globos y lirios; tres cálices, a modo de flores de almendro, con sus 
singulares interpretaciones dadas a algunos textos del Nuevo Testamento, en donde se reconoce explícitamente la autoridad imperial. Pero con la aparición de los reinos germánicos al quebrar el Imperio romano de Occidente, surge la necesidad de la legitimación de su estatus, incluso frente al imperialismo amenazante de Bizancio que destruyó a los ostrogodos e inquietaba a los visigodos en el Sureste peninsular ibérico. Ante esto, la monarquía goda encontró un inmejorable apoyo legitimador en el recuerdo de los reyes de Israel, y un brillante emblema programático en el árbol de Jesé. Este fue el padre de David y el texto profético se alude a una monarquía justiciera e ideal. Si los reyes godos no tenían sobre ellos la autoridad imperial, al menos se presentaban como sucesores de los reyes de Israel, y hasta eran ungidos por los obispos de Toledo como los reyes israelíes lo eran por los profetas. La flor de lis representa a Jesucristo como rey perfecto e ideal, pero también, por extensión, a una sociedad ejemplar, fuerte y pacífica, presidida por una autoridad sabia, justa y benévola con el pobre.

Los reyes de Navarra recogieron este emblema visigodo. Su feudalismo era pactista; el rey, sin tener sangre real, fue alzado y reconocido por los caballeros pamploneses. De esta manera el título era discutible. Su voluntad de ser reyes conforme a los cánones de la época quedó materializada en la aceptación del árbol crucífero, árbol de Jesé, como emblema real. Los reyes navarros estarían adornados con todas las virtudes que debe tener un rey: espíritu de sabiduría e inteligencia, espíritu de fortaleza, justicia para los pobres y equidad para los humildes; serían estandarte para los pueblos y vencerían a los enemigos de Dios. También es un emblema antimusulmán, de victoria cristiana. Los navarros vencerán al sarraceno como el vástago de Jesé, David y Jesucristo, es siempre vencedor de sus enemigos. En el texto concretamente, Edom y Moab, los hijos de Oriente y de Ammón.

globos y lirios, el segundo y lo mismo todos los seis brazos que salen del tallo. El tallo llevará cuatro cálices a modo de flores de almendro, con sus globos y lirios.

Ex. 37,17: Hizo de oro puro el candelabro, con su pie y su tallo de oro batido; sus cálices, sus globos y sus lirios hacian un cuerpo con él.

I Re. 7,19: Los capiteles que había en el extremo de las columnas del pórtico estaban moldeados en forma de lirio y eran de cuatro codos.

I Re. 7,22: Sobre el extremo de las columnas había tina moldura de lirios. Terminó así la obra de las columnas

I Re. 7,26: Tenía un palmo de grueso, y su labio estaba en forma de cáliz como una flor de lis.

Mt. 6, 28-29: $Y$ del vestido, ¿por qué preocuparse? Aprended de los lirios del campo, cómo crecen; no se fatigan ni hilan. Pues yo os digo que ni Salomón con toda su gloria se vistió como uno de ellos. 

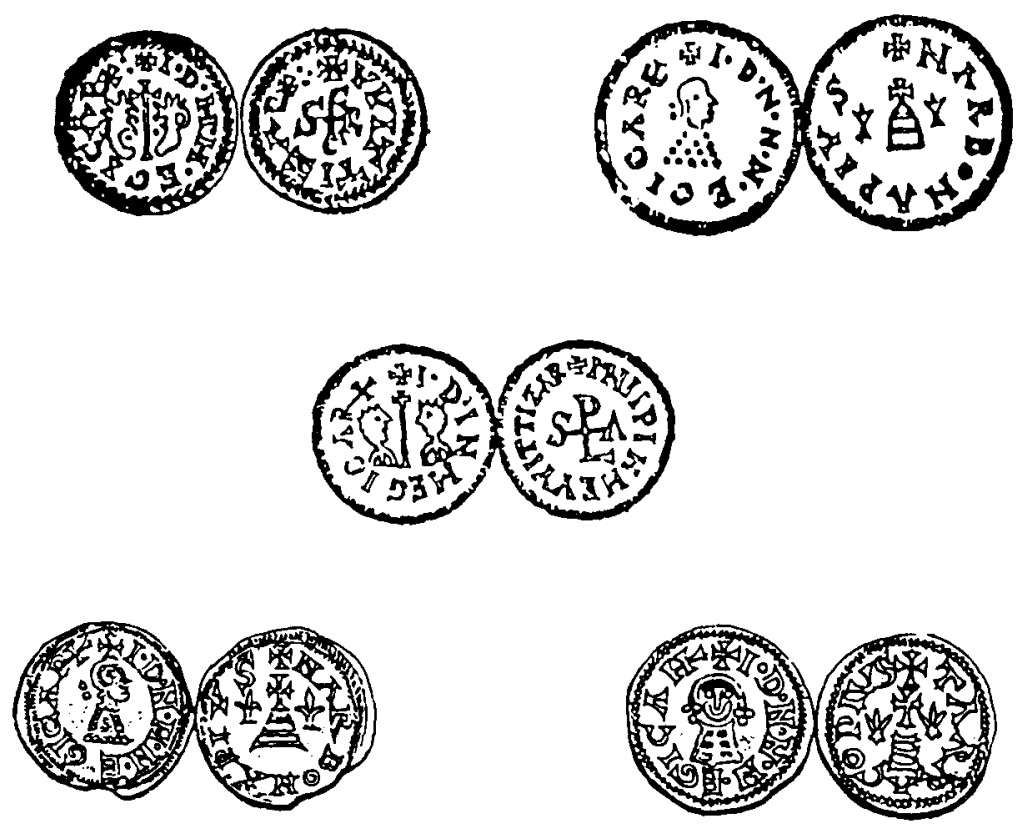

Fig. 4. Monedas visigodas con el Árbol de Jesé y flordelisada. Egica.

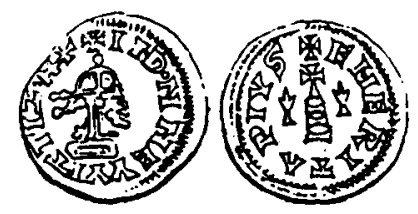

Fig. 5. Monedas visigodas con el Árbol de Jesé y flordelisadas. Vitiza. 

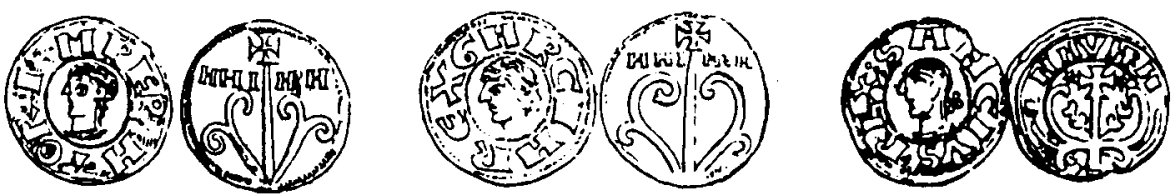

Fig. 6. Arbor ad modum floris o Árbol de Jesé (atribuidas a Sancho III, García III, Sancho IV).

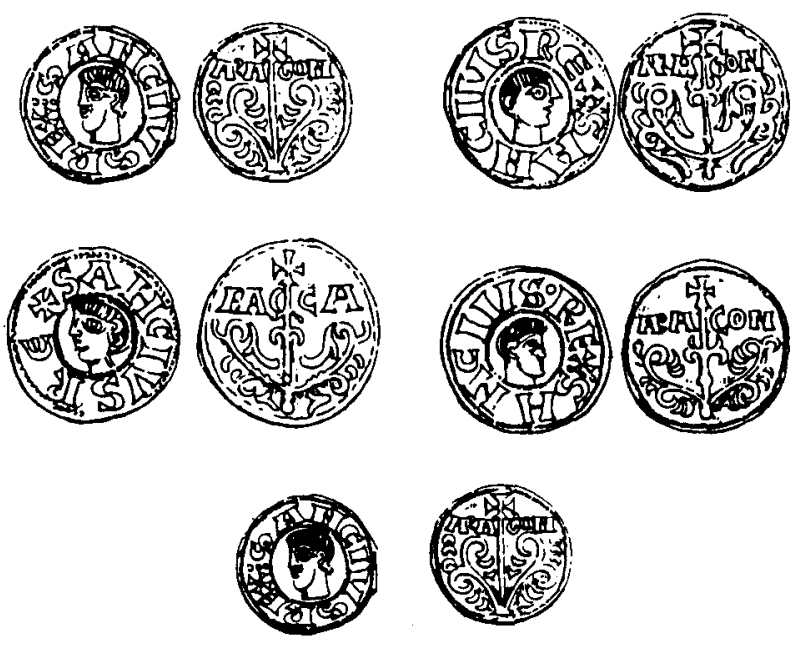

Fig. 7. Sancho V Ramírez.
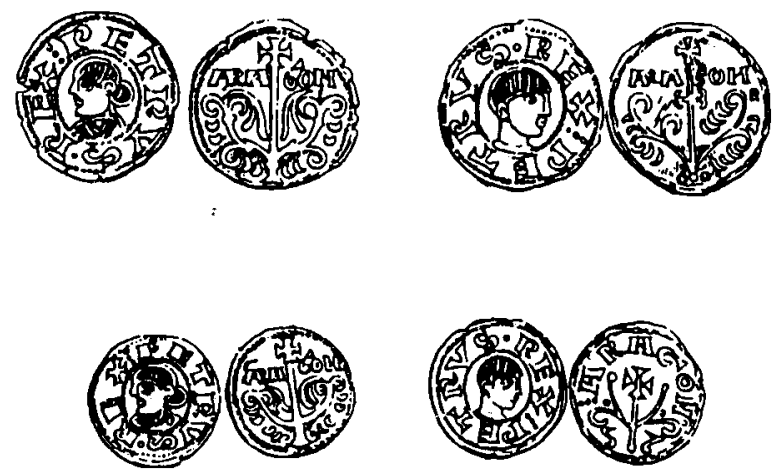

Fig. 8. Pedro I. 
Pero hay otro fortísimo motivo por el que los reyes navarros se presentan como sucesores de la monarquia visigoda. La aspiración de todo el período de la Reconquista es la recuperación de la pérdida de la monarquía visigoda. También esto ocurre en Navarra, que ve plasmado su sentir político y su concepción del mundo en la primera obra historiográfica que produjo, el Códice de Roda, custodiado en la Academia de la Historia, en Madrid. Se inicia el texto con los Siete libros de Historias contra los paganos, de Paulo Orosio, y obras históricas de San Isidoro de Sevilla como la Historia de los godos. Después vemos crónicas tan famosas como la de Alfonso III y la Albeldense; las famosas genealogías de Roda - Reyes de Pamplona, condes de Aragón, Pallars y Tolosa-, diversas nóminas reales, noticias sobre el origen de Roma, los reyes francos y la historia de los musulmanes. Sobreabunda el Códice en textos religiosos muy variados. Contiene también una carta del emperador Honorio a la milicia de Pamplona y un elogio de la ciudad. Finalmente un pequeño texto sobre Historia de Pamplona que se encuentra también en el Códice vigiliano, un obituario de obispos de Pamplona y un epitalamio. La disposición es progresiva y concéntrica. El reino de Navarra culmina, junto con León, la historia peninsular y son ellos los herederos de los reyes visigodos. El Códice de Roda presenta diversas cuestiones de carácter histórico y religioso, aborda una serie de problemas dogmáticos y tiene un credo de gran precisión. Todo esto es un reflejo de lo tratado en la iglesia visigoda. También, pues, la Iglesia navarra es una continuación de la antigua Iglesia católica goda.

Y si esto ocurre con el Códice de Roda, otro tanto puede decirse del Códice vigiliano o albeldense. Contiene una magníficda crónica de origen asturiano que el monje Vigila completó con datos sobre la Historia de Navarra. Comienza dicha crónica con una descripción del mundo y de España, una síntesis de Historia Universal desde Adán, datos de Geografía y sedes episcopales. Sigue con una Historia de Roma y de Bizancio, otra de los reyes visigodos, una sucesión de reyes astures y abundantes datos sobre los musulmanes. Finalmente, por obra del monje Vigila, una adición sobre los reyes de Pamplona. Es una narración de ambiciosas metas pues habla de Historia universal. Presenta una dispósición y estructura concéntrica y ascensional. La Historia universal se va limitando a la de Hispania, y ésta culmina en Asturias y Pamplona, sucesoras de la monarquía goda. Los otros contenidos del Códice corroboran esto: Un tratado de cronología, el Liber iudiciorum o la Colección canónica hispana... presentan al Derecho pamplonés como prolongación del antiguo Derecho visigodo y a la Iglesia de Pamplona como la continuadora y heredera de la Iglesia católica visigoda. 

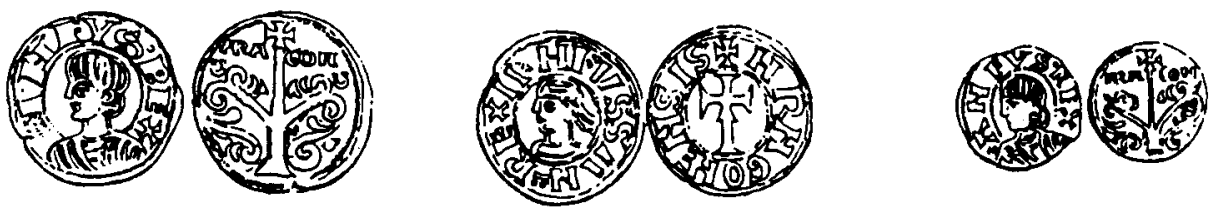

Fig. 9. Alfonso / el Batallador.

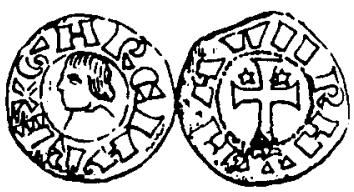

Fig. 10. García N el Restaurador.
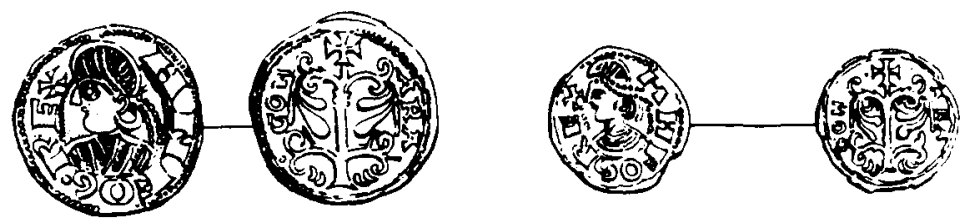

Fig. 11. Alfonso II.
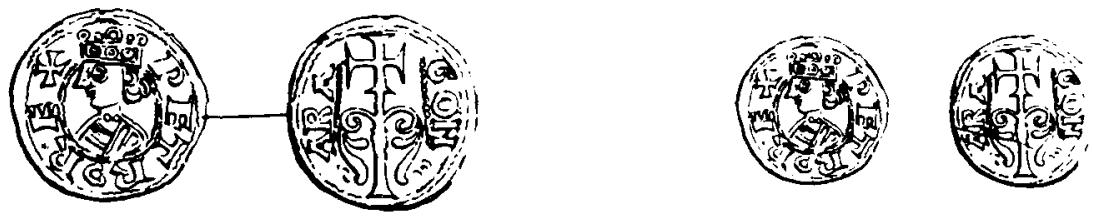

Fig. 12. Pedro II. 
También los ideales político-religiosos continúan. El árbol de Jesé, la flor de lis, viejos emblemas visigodos, son recogidos por la monarquía pamplonesa y también se usarán en Aragón, Cataluña y Valencia. ¿A qué se deberá esta fuerte expansión en el ámbito del Ebro? ¿Quizá a la relación existente entre tal símbolo y la familia real Égica-Witiza y descendientes, que tanto apoyo tuvieron en esta zona de España?

En cuanto a las estrellas que suelen aparecer junto al árbol crucífero, creo que también son alusiones bíblicas de victoria frente a los enemigos y los infieles. Así, cuando Débora venció al general Sisara y sus novecientos carros de hierro, "desde los cielos combatieron las estrellas, desde sus órbitas combatieron las estrellas, contra Sísara (Jue. 5,20). Hay muchas otras citas bíblicas que hablan del sol, la luna y las estrellas" ${ }^{18}$. Suelen presentarse como imágenes del esplendor y la majestad divina, del poder real. Creo que esta explicación de tal simbolismo es más razonable, o por lo menos complementaria, de la que da el P. Moret ${ }^{19}$. Quizá la única referencia a la luna musulmana sea la que aparece con las puntas hacia abajo, a los pies de un castillo, en monedas de Teobaldo I, Teobaldo II y Juan II. La fortaleza se parece mucho, aunque esquematizada, a las que se graban en monedas castellanas ${ }^{20}$. ¿Será un tra-

18 Ex. 32,13: “Yo multiplicaré vuestra descendencia como las estrellas del cielo...».

Núm. 24, 17: "Alzase de Jacob una estrella, surge de Israel un cetro".

Sal. 72,51: "Que dure tanto como el sol y permanezca ante la luna de generación en generación... Florezca en sus días la justicia, y haya mucha paz mientras dure la luna».

Sal. 74,16: "Tuyo es el día, tuya la noche, tú estableciste la luna y el sol».

Sal. 84,12: "Porque sol y escudo es Yavé".

Sal. 89, 37-38: "Su descendencia durará eternamente, y su trono permanecerá ante mí cuanto el sol, y como la luna subsistirá eternamente, y será testigo fiel en la nube".

Eclo. 136, 8-9: “...el sol para dominar el día, porque eterna es tu piedad; la luna y las estrellas para dominar la noche, porque eterna es tu piedad".

Eclo. 43: "...Sale el sol e irradia su calor, criatura admirable, obra del Altísimo... Es la luna faro de los campamentos en las alturas que alumbra al ejército desde los cielos... Hermosura del cielo es el resplandor de las estrellas, brillante adorno de las alturas del Señorm.

Eclo. 46,5: "iNo se detuvo al sol al tender su mano?"

Is. 30,26: "Y será entonces la luz de la luna como la luz del sol, y la luz del sol siete veces mayor, como la luz de siete días, el día en que Yavé vendará la herida de su pueblo y sanará la llaga de sus azotes".

Is. 60,19-20: “Ya no será el sol tu lumbrera de día, ni te alumbrará el resplandor de la luna, sino que Yavé será tu eterna lumbrera, y tu Dios será tu esplendor. Tu sol no se pondrá jamás, ni menguará la luna porque será Yavé tu eterna luz".

Ap. 1,16: "Tenían en su diestra siete estrellas, y de su boca salía una espada aguda, de dos filos, y su aspecto era como el sol cuando resplandece toda su fuerza".

Ap. 12,1: "Apareció en el cielo una señal grande, una mujer envuelta en el sol, con la luna debajo de sus pies, y sobre la cabeza una corona de doce estrellas".

19 Para el P. Moret, el origen de la luna y las estrellas que aparecen en algunas monedas navarras está en un estandarte arrebatado a los musulmanes en la batalla de las Navas de Tolosa. Pero tales imágenes también están presentes en monedas de fuera de Navarra.

${ }^{20}$ A veces, incluso con la vara de Jesé en lugar del torreón central. 
sunto, con sus torres, del Jerusalén celeste, de la ciudad de Dios ${ }^{21}$, como ejemplo para Pamplona?

Haré una última reflexión sobre la numismática navarra. En tiempos de Carlos II se acuñó en Navarra unas monedas, en vellón y plata, de estilo claramente arcaizante. En el anverso aparece unánimemente una cruz: y en el reverso, según la interpretación del $P$. Moret, hay sobre una "barrera de cadena" dos columnas unidas y acabadas en eslabones o lises, y que albergan tres círculos y una cruz sobre un triángulo. Para Moret los. eslabones son las cadenas de Navarra y las tres esferillas son los estados de Champaña, Bría y Borgoña. Realmente son insostenibles tales ideas. En la única moneda de Carlos II en que se plasman las cadenas, se hace de muy distinta forma, y la propia imagen analizada no tiene conexión lógica con las ideas de Moret. Pero todo cambia si nos fijamos en las monedas castellano-leonesas, y hasta en las de Aragón y Valencia. Veremos que muchos reyes están representados con coronas muy parecidas al dibujo que nos ocupa: son coronas perladas que alguna vez se rematan en una cruz. Coronas de gratísimo simbolismo para la Biblia ${ }^{22}$.

${ }^{21}$ Sam. II 5,7: «Pero David conquistó la fortaleza de Sión que es la ciudad de David".

Nehemías 6,15.16: “la muralla quedó terminada el día veinticinco de Elul... y reconocieron que esta obra había sido realizada por nuestro Dios".

Tb. 13,12: “iMalditos sean cuantos te destruyan! iCuantos derriben tus muros, echen tus torres por tierra y pasen a fuego tus moradas!

Sal. 122,6-7: Pedid la paz para Jerusalem: ien calma estén tus tiendas, haya paz en tus muros, en tus palacios calma!"

Is. 60,17-19: «Te pondré como gobernantes la paz, y por gobierno la justicia. No se oirá más hablar de violencia en tu tierra, ni de despojo o quebranto en tus fronteras, antes llamarás a tus murallas "Salvación". No será para ti ya nunca más el sol luz del día, ni resplandor de la luna te alumbrará de noche, sino que tendrás a Yavé por luz eterna, y a tu Dios por tu hermosura».

Jer. 4,5-6: “iJuntaos, vamos a las plazas fuertes, izad bandera hacia Sión!».

Zac. 2,9: "Y yo seré para ella -oráculo de Yavé- muralla de fuego en torno, y dentro de ella seré gloria".

22 Lev. 8,9: «...cubrió su cabeza con la tiara, poniendo en la parte anterior de ella la diadema de oro, la diadema de la santidad, como lo había mandado Yavém.

II Reyes 11,12: "Sacó al rey, púsole la diadema y los brazaletes y le ungio".

I Macab. 1,9-10: «En su lugar entraron a reinar sus generales, los cuales, en cuanto él murió, se ciñeron diadema"

I Macab. 6,5: “...entregándole la diadema, el manto real y el anillo".

I Macab. 10,20: “... y le envió un vestido de púrpura y una corona de oro".

I Macab. 11,13: «entró Tolomeo en Antioquía y se ciñó a su cabeza dos diademas, la de Asia y la de Egiptom.

Sal. 21,4: “...y pusiste en su cabeza la diadema de oro puro".

Sal. 132,18: "A sus enemigos los vestiré de ignominia, y brillará sobre él mi diadema".

Is. 61,3: "...y dar a los afligidos de Sión, en vez de ceniza, una corona".

Is. 61,10: “...como esposo que se ciñe la frente con diadema...".

Is. 62,3: “...serás en la mano de Yavé corona de gloria, real diadema en la palma de tu Dios". 

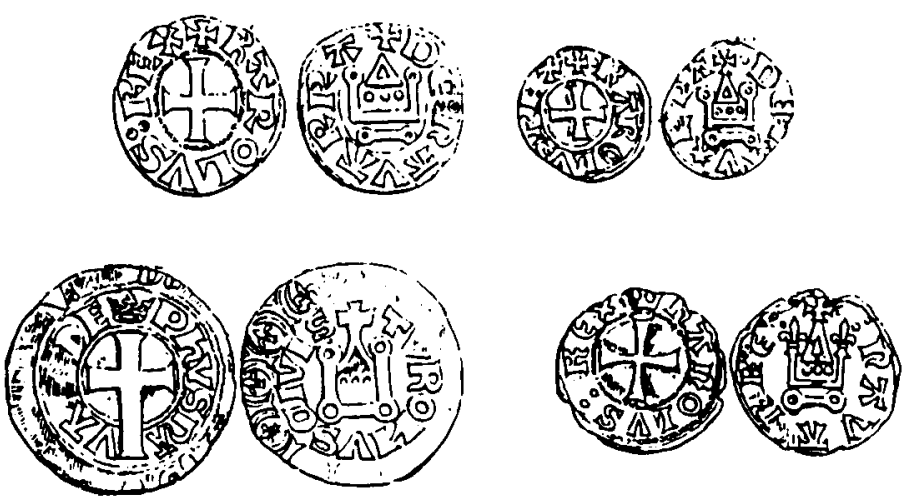

Fig. 13. El emblema de la Corona. Navarra.
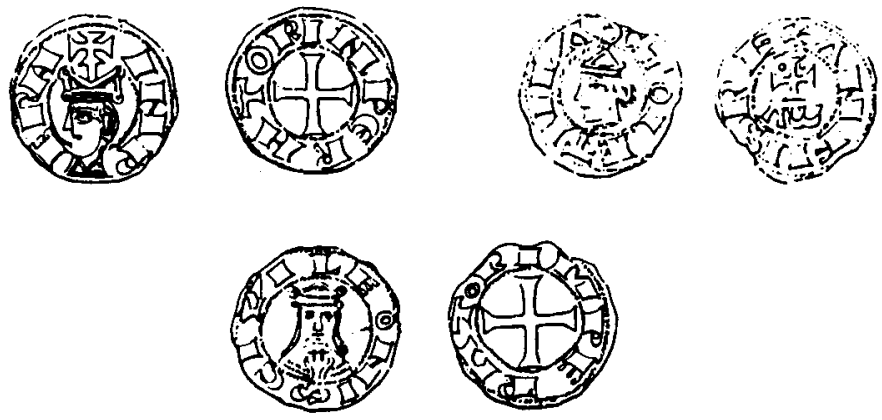

Fig. 14. Castilla.

Vistas las cuestiones del árbol crucífero, el «águila negra» y la numismática navarra, revisemos ahora el tema de las cadenas. Afirma $\mathrm{F}$. Menéndez Pidal que la leyenda de las cadenas del Miramamolín se plasmó muy tardiamente en un emblema para Navarra. Desde luego la Crónica

Ap. 2,10: "Se fiel hasta la muerte y te daré la corona de la vida".

Ap. 19,12-13 «Sus ojos son como llama de fuego, lleva en su cabeza muchas diademas y tiene un nombre escrito que nadie conoce sino él mismo, y viste un manto empapado en sangre, y tiene por nombre Verbo de Dios". 
del Príncipe de Viana ya la contempla ${ }^{23}$. El problema es saber cuándo surge. Los sellos y relieves en ningún caso nos ofrecen garantía alguna, pues corremos el riesgo de juzgar como cadenas lo que sólo es la bloca del escudo. No ocurre lo mismo con las monedas del reino de Navarra. No representaron un escudo con bloca o cadenas ni antes de las Navas de Tolosa ni un siglo y medio después, como tampoco el «águila negra» ni escudo alguno. Por tanto, si brúscamente, en un momento determinado, surgen la bloca o cadenas, es que algo singular habrá ocurrido, tanto como para que se plasme un escudo en las monedas y aparezca como símbolo típicamente real y heráldico. $Y$ esto no puede ser sino la aceptación y extensión de la historia de las cadenas rotas, lo cual ocurrió en tiempos de Carlos II el Malo (1349-1387). La primera moneda del reino de Navarra con círculos y barras radiales cerradas en los bordes del escudo es un vellón blanco con las leyendas "Dei gratia Navarre rex" en el anverso, y "Comes Ebroicensis" en el reverso. Esta imagen ya no es producto del viejo tema de la bloca de los escudos, sino que responde a un concepto nuevo. No es razonable representar simplemente un escudo con su bloca de refuerzo y sin ninguna otra imagen ni significado. Menos todavía en una moneda y en el siglo XIV, cuando la heráldica y su simbología están muy desarrolladas.

Hasta aquí hemos visto diversos aspectos de la emblemática navarra en la Edad Media. Los símbolos empleados son referencias bíblicas. Buscan justificar el poder, el ejercicio del mando, y también proponer un modelo de comportamiento político y social. No se trata de unas imágenes cualesquiera, elegidas al azar, sino que tienen, un significado profundo y gran valor intelectual. Sospecho que buena parte de los emblemas medievales europeos son originariamente referencias bíblicas, pues la Biblia es parte de la cultura viva, goza de lectura constante y preside la vida intelectual del momento. Es más, una de las singularidades de la Heráldica europea que nace en el siglo xil es precisamente tener un origen bíblico que le otorga unidad y lógica. $Y$ es que además de su contenido teológico, moral y social, la Biblia tiene un valor literario de primerísimo orden y su simbolismo y metáforas son poderosas herramientas para representar las naturales aspiraciones del hombre, tanto en el ámbito social como en otros muchos: el águila, el león, el toro, el caballo, la gacela y el ciervo, la espada, las lanzas, las llaves, el agua y la sangre, una torre o una fortaleza, los escudos, las distintas variedades de árboles y flores, las cruces, las trompetas, el arpa, el corazón, las estrellas, la luna, los dra-

23. "Él conquistó las cadenas por armas, et assentolas sobre las ariestas con un punto en medio de sinople». 
gones, las piedras preciosas... y aún muchas otras imágenes podemos encontrar en sus páginas, y trasladadas además a la heráldica europea. Dese luego, hay blasones que son descriptivos, como el castillo de Castilla o el León del reino de León. Pero incluso aquí hay una apelación al valor superior y trascendente de la comunidad y del grupo, de la patria y el bien común. En el actual escudo de España, casi todas las imágenes son, total o parcialmente, de origen bíblico. La corona real, la presencia misma del escudo ${ }^{24}$, las flores de lis, los cetros de Aragón ${ }^{25}$, el león ${ }^{26} \mathrm{O}$ el castillo corresponden a imágenes de las Sagradas Escrituras. Esto mismo puede decirse, por ejemplo, de Inglaterra. ¿De dónde surgen en su heráldica tantos leones si no son animales propios de la región? Solamente la Biblia y los escritos de los Padres de la Iglesia pudieron ser la fuente inspiradora. Creía Mateu y Llopis que la presencia del uarbor ad modum floris» en lugares tan dispares como Dinamarca, Navarra o Valencia se debe a la fácil difusión de los tipos numismáticos. Pero la difusión de una imagen tan rara, ino estaría facilitada por las comunes ideas de una sola "universitas christiana»?

Muchos han sido los intentos realizados para explicar el origen de la Heráldica: la distinción entre guerreros, la influencia oriental sobre los cruzados, los torneos y juegos caballerescos, concesiones reales de carácter ennoblecedor... Eduardo Pardo de Guevara afirma en su manual que el uso de los emblemas se debió a la necesidad de distinción de los guerreros, irreconocibles en sus armaduras. Jorge Luis Zarazaga, en su obra "Qué es la Heráldica», centra su atención en el Oriente como impulsor de la heráldica europea pues observa que los términos con que se designan los colores tienen esa procedencia. Pero si cierta tendencia al simbolismo deriva del contacto de los cruzados con los árabes, los contenidos concretos de las figuras heráldicas los relaciona con diversos

${ }^{24}$ I Sam 17,6: «A los pies llevaba botas de bronce, y a las espaidas un escudo, también de bronce».

Is 21,5: “i Arriba, príncipes, a engrasar el escudo»!

II Sam. 22,3: «Mi Dios, la roca en que me amparo, mi escudo, mi poder salvador, mi inaccesible asilo".

Sal 5,13: "Pues al justo, ioh Yavé!, Tú le bendices y le rodeas de tu benevolencia como un escudo".

Ef. 6, 16: «Embrazad en todo momento el escudo de la Fe, con que podáis detener los encendidos dardos del maligno".

${ }_{25}$ Am. 1,5: "Yo quebrantaré las barras de Damasco y exterminaré a cuantos habitan en Biqat-Awen y a quien empuña el cetro de Bet-Edén».

Gen. 49,10: "No faltará de Judá el cetro, ni de entre sus pies el báculo".

26 Gen. 49,9: "Cachorro de león, Judá, de la presa subes, hijo mío".

Prov. 19,12: "Rugido de león es la ira del rey". 
ámbitos. Así, cree que las figuras de animales y su significado está en conexión con los bestiarios antiguos y medievales, o con sus características innatas. Sólo en los capiteles románicos les añade algún concepto religioso. Por ejemplo, el águila, que puede renovar su plumaje, representa la renovación espiritual del hombre. El mismo error comete con las plantas de las que dice "Similar significación simbólica tienen las plantas de acuerdo con cánones tradicionales y con las características de su naturaleza, que las ha cargado de una preocupación determinada». A la flor de lis la califica de atributo de la monarquía, sin decir por qué y sólo en manos de la Virgen María le da algún calificativo moral. Ya sabemos que la flor de lis no es un símbolo adherido a la realeza sino al contrario; la realeza fue quien buscó asemejarse al que era y representaba la flor de lis. Vicente de Cadenas y Vicent afirma que la Armería «posiblemente sea el directo producto del contacto entre Occidente y Oriente con el motivo fundamental de las Cruzadas...". Pero si se ve en los musulmanes y sus costumbres la causa material del simbolismo heráldico, seguidamente reconoce como causa final del mismo la necesidad de diferenciar y reconocer a los caballeros armados con coraza. Ingenuamente, alega como prueba demostrativa del carácter oriental de la Heráldica la inexistencia de leones y dragones en Europa y, estrepitosamente, relaciona el dragón con el cocodrilo, icomo si no hubiese dragones en la Literatura, las leyendas y la cultura europeas! Pero es Faustino Menéndez Pidal el que más se acerca al núcleo del problema. Hablando de la representación heráldica del león en tiempos del rey Fernando II, le asigna en primer lugar un carácter parlante. El león representa al territorio del reino de León. También representa a la fuerza y el poder, y por extensión a la del rey. Ambos son calificados en los textos con el calificativo "fortis". Se considera al león el rey de los animales y, por tanto, digno emblema de un monarca. Finalmente, F. Menéndez Pidal encuentra un simbolismo cristiano en las estilizadas representaciones de águilas y leones heráldicos; representaciones muy semejantes a las que se hacen en los capiteles románicos. Pero tales apreciaciones no son del todo correctas pues el simbolismo cristiano lo considera marginal, secundario. Quizá se fíe demasiado de Don Ramiro de Pinedo ${ }^{27}$ que ve en la escultura medieval un contenido religioso agregado y subordinado a imágenes y significados seculares precedentes. Para Ramiro de Pinedo, las flores de lis son unas «fantásticas flores heráldicas que no existen en la naturaleza" y significan abolengo regio. Se trata pues de un significado laico, puramente político, que se atribuye casualmente a Cristo, representado en los capiteles románicos,

27 Ramiro de PINEdo, Dom, El simbolismo en la escultura medieval española. Madrid 1930. 
siguiendo a las metáforas bíblicas, por una rosa o un lirio sobre los lises. Afirma también que los cuatro pétalos del lirio se corresponden con los cuatro elementos de la naturaleza, tierra, agua, aire y fuego, y representan la humanidad de Cristo. El desconocimiento del origen de los símbolos y emblemas pudo provocar tal construcción cuando se labraron los capiteles, y la posterior interpretación de Pinedo. Sin embargo, sabemos que la flor de Jesé es una flor genérica referida a Cristo como rey. Su imagen fue entendida posteriormente como un lirio visto lateralmente $y$ desde una de sus diagonales, fundiéndose así dos de sus pétalos en uno solo. Los lises no serían flores fantásticas sino lirios. De hecho, en francés lis significa lirio. La utilización por los poderes públicos de esta imagen terminó por consolidar la idea de flor de lis como emblema real. Hubiese bastado con representar un lirio, un lis para representar a Cristo como rey y señor; pero este significado se olvidó y los lises fueron tenidos como la imagen de reyes temporales. Pinedo relaciona a la flor de Jesé con Cristo, como hace con los lirios, pero no la conecta con la realeza a pesar de ser evidente en el texto de Isaías. Le falta una conexión imagen-concepto por el proceso de secularización de la emblemática. Un laberíntico camino, a partir del famoso árbol de Sobrarbe, nos ha llevado a reconocer los originarios símbolos cristianos, copiados después por el poder político.

La representación de un ideal, un grupo político o una creencia religiosa mediante imágenes y símbolos es algo propio de la naturaleza y carácter del hombre, y puede encontrarse en cualquier época o cultura. Hemos visto ejemplares entre griegos, romanos y godos. En los primeros siglos de la Edad Media encontramos símbolos religiosos y reales en toda Europa. Están presentes en basílicas, monasterios, libros, monedas, joyas y armas. Tras este período de símbolos, aparece quizá hacia fines del siglo $x \mid$ y desde luego en el XII unas señales distintivas más exclusivistas, de carácter personal y territorial, lo cual no quiere decir que antes no hubiese medios diferenciadores. En el siglo XII estas señales se funden con la silueta de un escudo y se representan separadas de cualquier otra imagen. El escudo se convierte en un soporte convencional, abstracto; un elemento más del emblema y su significado, que puede ser personal, territorial, jurídico o religioso. Este momento lo podríamos calificar como de alta Heráldica y se extiende en los siglos $x \mid$ y $x I I$. Posteriormente se populariza el uso de la heráldica y se extiende a todos los niveles sociales. Es la baja heráldica de los siglos XIV y $\mathrm{xV}$. Con mayor o menor valor 


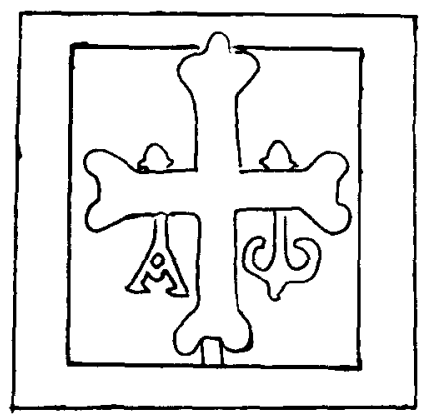

Fig. 15. Lises medievales asturianas y leonesas. San Martín de Salas (siglos $(x-x)$.

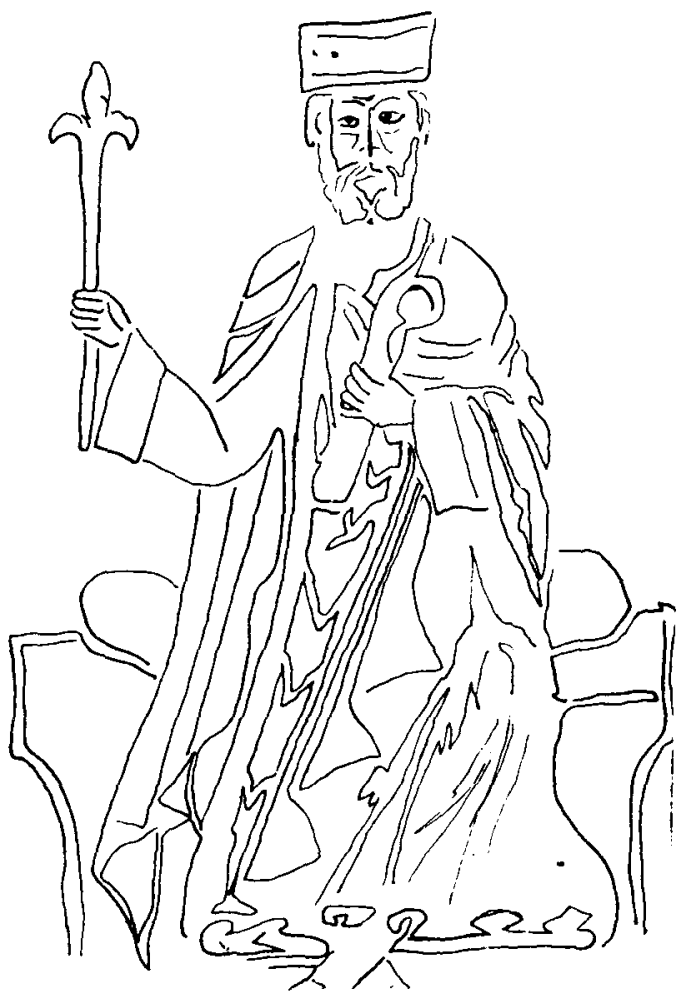

Fig. 16. Bermudo III. Tumbo A de la catedral de Santiago. 
simbólico o heráldico, personal o territorial ${ }^{28}$, los símbolos reales usados en Navarra han sido, además de los bustos reales, el árbol crucífero o de Jesé, quizá desde Sancho el Mayor; las estrellas, que podemos verlas en monedas de Sancho IV, y con la luna en monedas de Sancho VII el Fuerte; las grandes cruces de Alfonso el Batallador; los guerreros con escudos blocados de Sancho el Sabio, y el «águila negra" de Sancho VII el Fuerte. Con Teobaldo I la casa de Champaña se introduce el escudo rojo ${ }^{29}$ como símbolo de Navarra, al que se añade el color azul y la banda

${ }^{28}$ No comparto la opinión de Faustino Menéndez Pidal sobre la división tajante entre los emblemas personales y territoriales, a propósito de dos sellos de Fernando lll el Santo y Sancho VII el Fuerte, en donde el castillo y el águila aparecen flanqueados por dos leoncillos. Raro parece que un rey haga representar su persona por una señal territorial y duplicada, de otro reino, que fue gobernado por un pariente lejano o por línea materna. La auctoritas real es, además, una cualidad personalísima que otorga una fuerte identificación entre el rey y el reino. Si los leones representan un linaje, creo que también puede reconocérseles un sentido político, una aspiración y programa de dos reyes que sufrieron muchos problemas por su propio trono, plasmando sus relaciones familiares con Alfonso VII, que alcanzó el título de emperador, máxima legitimidad sociopolítica y emanadora de autoridad.

${ }_{29}$ Para F. Menéndez Pidal el origen del color rojo está en las armerías imaginarias de la literatura francesa del siglo xIII. Pero, a su vez, ésta pudo inspirarse en los textos bíblicos, en donde los colores tienen también un notable significado; en particular el color rojo y el rojo de la sangre. Veamos algunos ejempios.

Ex. 25,3-5: «He aquí las ofrendas que recibiréis de ellos: oro, plata y bronce; púrpura violeta y púrpura escarlata, carmesí, lino fino y pelo de cabra; pieles de carnero teñidas de rojo y pieles de tejón”.

Ex. 26,1: «La morada la harás de diez cortinas, de hilo torzal de lino fino, teñido de púrpura violeta, púrpura escarlata y carmesim.

Ex. 26, 14: «Harás también para el Tabernáculo una cubierta de pieles de carnero, teñidas de escarlata".

Ex. 26,31: “Haz también un velo de lino torzai, de púrpura violeta, púrpura escarlata y carmesím.

Ex. 27,16: «Para la entrada del atrio habrá un velo de veinte codos, de lino torzal en púrpura violeta, púrpura escarlata y carmesi».

Ex. 35,5-6: «Tomad de vuestros bienes para hacer ofrenda a Yavé. Ofrezcan todos voluntariamente una ofrenda de oro, plata, bronce, jacinto, púrpura, carmesí, pelo de cabra, pieles de tejón teñidas de rojo".

Ex. 36,8: "Los hombres hábiles, de los que trabajan en la obra, hicieron el habitáculo de diez cortinas de hilo torzal, de lino, jacinto, púrpura y carmesín.

Lev. 1,5: "Los sacerdotes, hijos de Arón, llevarán la sangre y la derramarán en torno al altar..."

Lev. 8,30: "Tomó Moisés el óleo de unción y sangre de la que había en el altar...".

Is. 63,1: "¿Quién es aquel que avanza de Edom, rojos los vestidos, de Basra, aquél tan magnífico en su vestido, avanzando en la plenitud de su fuerza?"

Yo soy el que habla en justicia, un gran libertador.

¿Y porqué está de rojo tu vestido, y tu ropaje como el de un lagarero?

El lagar he pisado yo solo, de mi pueblo no hubo nadie. Los pisé con ira, los pateé con furia, y salpicó su sangre mis vestidos, y toda mi vestimenta he manchado. Era el día de la venganza que tenía pensada, el año de mi desquite era llegado. Miré bien y no había auxiliador, me asombré de que no hubiera quien me apoyase. Así que me salvó mi propio brazo, y fue mi furia la que me sostuvo. Pisoteé en mi ira, los pisé con furia e hice correr por tierra su sangre». 
blanca de Champaña. Los Teobaldos también tuvieron en sus monedas el símbolo de la fortaleza con la luna a sus pies, que igualmente usó Juana I. La casa de Evreux traerá de Francia las flores de lis, y así, en tiempos de Carlos II, vemos que la numismática navarra contiene cruces, lises, coronas naturalistas y arcaizantes, y el primer escudo numismático blocado o mejor con cadenas, otro ejemplo de arcaísmo e historicismo. Vemos que ha habido una evolución a lo largo de la Historia y que en un momento determinado pueden convivir más de un emblema. Pero el tiempo y la aceptación social han consagrado de forma definitiva a las cadenas de Sancho el Fuerte como el emblema de Navarra.

\section{LA EDAD MODERNA}

Y finalmente llegamos a la Edad Moderna. Si en la Edad Media los primeros emblemas territoriales se combinan entre sí para referirse a las personas de los reyes, si incluso aparecen emblemas máximamente personalizados al referirse a linajes nobiliarios, ahora nos encontramos con una heráldica más complicada. Hay escudos de linaje, escudos de dominios, escudos de coronas y territorios (por ejemplo los emblemas de Castilla y León solamente), emblemas de legitimidades históricas y dominios poseídos en el pasado, escudos de pretensiones territoriales, y aún otros más. Aparecen los blasones en palacios, iglesias, fortalezas, catafalcos, tapices, libros, obras de arte, joyas, armas, barcos, banderas, monedas, sellos, ropas...

El matrimonio de los Reyes Católicos significó la aparición de un bello escudo cuartelado, con los dos contracuarteles de San Fernando y dos cuarteles partidos de Aragón y Sicilia. La reina Isabel muere en 1504, pero la primera regencia de Fernando el Católico se vio bruscamente interrumpida por la presencia de Juana la Loca y Felipe el Hermoso. El escudo de los nuevos reyes será complejísimo. Las armas de los Reyes Católicos, ahora generalmente con un partido de Aragón y Jerusalén-Hungría $\left(2^{\circ}\right.$ cuartel); y un partido de Aragón y Sicilia ( $3^{\circ}$ cuartel), ocuparán dos cuarteles. Las del nuevo rey Felipe, otros dos, pero dejando la primacía a Castilla-León. Estas armas eran Austria, Borgoña moderna o Artois, Borgoña antigua y Brabante; y sobre el todo, partido de Flandes y Tirol. A veces se simplificaba haciendo un escudo cortado, con las armas his-

Ap. 19,12-12: "Sus ojos son como llama de fuego, lleva en su cabeza muchas diademas y tiene un nombre escrito que nadie conoce sino Él mismo, y viste un manto empapado en sangre, y tiene por nombre Verbo de Dios". 
panas en la parte superior y las extranjeras en la inferior. Este esquema será paradigmático durante los reyes Austrias y en parte con los dos primeros Borbones. La rápida muerte del rey Felipe y la locura de su esposa significaron la segunda regencia del rey Fernando el Católico, entre 1506 y 1516.

El 25 de julio de 1512, el Duque de Alba entraba en Navarra. En los primeros días, el rey Fernando el Católico se tituló “Depositario de la corona de Navarra y del reino, y del señorío y mando de él». Pero a la vista de la bula "Pastor ille caelestis", publicó un manifiesto en el que se titulaba rey de Navarra. En 1513, el virrey de Navarra, marqués de Gomares, juró en Pamplona observar los fueros, leyes y privilegios. Finalmente, en julio de $1515^{30}$, las Cortes Castellanas reunidas en Burgos, incorporaron Navarra a Castilla.

¿Qué es la incorporación de Navarra a la Corona de Castilla, o la unión de Navarra a Castilla? En principio, dos reinos pueden tener un solo rey sin por eso unir sus destinos, aun cuando esto sea lo normal; o pueden ensamblarse en una sola corona indivisible; o incluso pueden fundirse, resultando un solo reino con unas mismas instituciones. En el caso de Navarra hay que preguntarse inicialmente cómo manejaba con tanta facilidad al reino, trasladándolo de la Corona de Aragón a la de Castilla. Un rey es propietario de la realeza, de su título real, no del reino. En la Alta Edad Media podía repartir la corona entre sus hijos, pero no entregar el reino a dinastías extrañas. En la Baja Edad Media las instituciones se consolidan y la propia realeza es indivisible. En mayor medida un rey no debería disponer arbitrariamente de los derechos de sus súbditos y sus instituciones. Si su «auctoritas" tiene ciertas directrices, más aun el ejercicio de la «potestas». En principio, Fernando el Católico no podía romper la unidad de la Corona de Aragón, ya indivisible, y menos si no era para entregar la realeza a su nieto, sino para injertar a Navarra en un reino extraño del que él no era rey sino sólo regente. Hipotéticamente, el rey católico pudo tener hijos con Germana de Foix, o Juana la Loca perder su descendencia, con lo que Castilla y Aragón hubiesen seguido caminos distintos. ¿Cómo un rey podía imponer en uno de sus reinos una sangre real extraña y atentar contra los derechos de su hipotético sucesor? Más to-

30 Acta de incorporación del Reino de Navarra a la Corona de Castilla: «Y que Su Alteza mandaba que las cosas que tocasen a las ciudades y villas y lugares del dicho Reino de Navarra y a los vecinos de ellas, conociesen desde ahora los del Consejo de la dicha Reina doña Juana, nuestra señora, y administrasen justicia a las ciudades, villas y lugares del dicho Reino...".

FLoRISTÁn ImizCOz, Alfredo, La Monarquía Española y el Gobierno del Reino de Navarra (15121808). Pamplona 1991. 
davía cuando el rey Fernando había jurado unos fueros que tenía que cumplir, y el reino de Navarra tenía sus derechos tradicionales inviolables.

¿Se incorporó Navarra a la Corona de Castilla? ¿Coincidió simplemente con Castilla en tener un mismo rey, una misma casa real para siempre, pero conservando sus instituciones y un estatus de reino distinto? En este caso es extraño que se comenzase a gobernar desde el Consejo de Castilla y no desde el Consejo Real de Navarra. Y aún más el que los navarros tuviesen grandes posibilidades en Castilla, por ejemplo en la ocupación de cargos, y no tantas los castellanos en Navarra. En el caso de que efectivamente el reino de Navarra hubiese pasado a formar parte de la Corona de Castilla, ésta debió cambiar de nombre pues del reino de Navarra procedía la realeza de Castilla y, por tanto, debía emplearse el término Corona de Navarra. ¿Acaso se pretendía fundir al reino de Navarra en Castilla, con la concesión regia de conservar fueros? Entonces no tenían que mantenerse las Cortes y otras instituciones si se deseaba una verdadera integración. Tema distinto es que el proceso centralizador castellano estuviese tan elaborado que para el ambiente de la época incorporarse a la Corona de Castilla equivaliese a ser ensamblado irremediablemente al reino de Castilla.

Técnicamente, el rey Fernando debió haber reconocido la unión de tres coronas, la de Castilla, la de Aragón y la de Navarra, que es lo que fácticamente había ocurrido. Y esto, en principio y sólo en principio, podía ser un factor aglutinador pues la naciente España corría menos peligro de dividirse en dos coronas, la de Castilla y la de Aragón, de acuerdo con la existencia de dos casas reales. La existencia de un reino difícilmente adscribible a uno de los dos ámbitos sería un obstáculo para la división. Pero había fuertes motivos para integrar a Navarra en Castilla. En principio se conseguía implicar a los aguerridos castellanos en la problemática defensa del nuevo reino frente a Francia. Además se controlaría mejor a Navarra si se insertaba en el ámbito castellano pues aquí el rey era más poderoso que en Aragón. Finalmente, quizá conviniese alejar la realeza navarra de la argonesa pues Aragón tenía pleitos con Francia en la larga frontera catalano-aragonesa y no era oportuno enfrentase a un pretendido rey de Navarra apoyado por Francia, con otra pretendida titularidad real navarra por parte del rey de Aragón. De hecho, ya desde el primer momento tras la conquista se presentan dificultades. El vizcondado de Castelbón, próximo a Seo de Urgell y usufructuado por Catalina de Navarra, causó graves disturbios al rey católico. De la sangre real navarra derivaba la realeza aragonesa que tenía menos antigüedad y cierta dependencia moral de Navarra. Los muchos lazos feudales subsistentes entre los reyes y los señoríos fronterizos podian servir de pretexto para choques frontales e incluso pérdidas territoriales de Aragón ante el pre- 
tendiente al trono navarro, apoyado por Francia, pues su alta legitimidad histórica podía ser punta de lanza para justificar una intervención. No hace falta insistir en la importancia de esto si, como efectivamente ocurrió y hasta era previsible, el título de rey de Navarra era incorporado a la Corona de Francia. Las formalidades pudieron aconsejar el apartar a Navarra del contencioso aragonés.

Lo que ocurrió en 1512 fue lisa y llanamente una apropiación de un reino por otro. El ocupado fue dominado e injertado en otro. Pero no era una invasión con fines económicos, para explotar al vencido, o a causa de odios dinásticos. Entre el gigante castellano y el gigante francés se encontraba el reino de Navarra, preferentemente en la vertiente sur del Pirineo y con fuertes lazos culturales, políticos e históricos con la Península Ibérica. Esta estratégica vía de penetración tenía que ser suprimida para evitar el peligro de una invasión o las sospechosas fluctuaciones de Navarra. Una vez conseguido esto, el conquistador castellano permitió a los navarros mantener todo su bagaje político y administrativo y otras notables ventajas pues le bastaba con el control territorial y militar, y deseaba la amistad del pueblo. Buena prueba es el abandono de la Baja Navarra, que se hizo por razones militares y lógicamente sin una actitud ambiciosa de conservar todos los territorios del pequeño reino, como hubiese sido de esperar. Pero todo ello se hizo por graciosa concesión del vencedor.

La ventajosa situación jurídica y política que se encontró Navarra tras su conquista e incorporación a Castilla se debió a una graciosa concesión del vencendor castellano, el cual pudo haber impuesto unas condiciones más duras. Navarra; como Granada, Canarias o los territorios americanos, es Navarra pero también Castilla pues fue ocupada y sus reyes expulsados; y la violencia es la última «ratio» del derecho positivo en todo tiempo y lugar. Además se han de tener en cuenta otros factores legitimadores, como la voluntad de buena parte de los navarros, y el general ambiente centralizador y aglutinador al calor del naciente estado moderno, de la cultura política del momento que consiste en el poder absoluto del rey. Fernando el Católico y sus sucesores mantuvieron los fueros como pudieron haberlos suprimido si hubiesen querido. $Y$ esta generosidad del vencedor permitió posteriormente a los navarros idealizar el hecho de la conquista y presentarse como detentadores de derechos inmanentes a su reino. La teoría de la Unión eque-principal fue un ardid hecho en 1645 por las Cortes de Olite para que los navarros mantuviesen sus privilegios en Castilla, como castellanos, sin que por ello hubiese argumento para fundir a Navarra en las instituciones castellanas. Así, Navarra se conservaba para los navarros, mientras que a los castellanos se les "filtraba" con el requisito de la naturalización. Al integrarse Navarra en la absorvente 
y uniformadora Castilla se podía esperar que Navarra fuese soldando sus instituciones con las castellanas. Pero no fue así y se llegó a una extraña situación en la cual los conquistados adquieren una relevante posición socio-política que no alcanza a los vencedores. En la Edad contemporánea se ha mantenido este desequilibrio tan difícilmente conciliable con el dogma de la soberanía nacional y de la igualdad entre todos los ciudadanos. Así, hubo momentos en que los navarros estaban libres del servicio militar.

Todo esto, el que Navarra fue también Castilla, quedó bien reflejado en la emblemática. El matrimonio de los Reyes Católicos dio lugar a un bello escudo cuartelado con los contracuarteles de San Fernando (1-4) y un partido de Aragón y Sicilia (cuarteles 2-3). Tras la conquista de Navarra, Fernando el Católico plasmó las cadenas de Navarra en el cuartel 2 de su escudo de armas, poniendo un partido de Aragón cortado de Navarra (1) y Jerusalén-Hungría (2). En el escudo de linaje $u$ oficial de la reina Juana y su marido, no aparecen las cadenas de Navarra. Es entonces cuando se forma un monumental escudo en contracuarteles aragoneses contienen un partido de Aragón y Jerusalén-Hungría (2), y un partido de Aragón-Sicilia (3). Pero al enviudar la reina, aparece en algunas ocasiones, en el cuartel 2 de las antiguas armas de sus padres, un partido de Jerusalem y Navarra. El escudo de linaje de Carlos I es el mismo que el de sus padres pero debe añadírsele las columnas y el águila bicéfala. Los contracuarteles aragoneses pueden ser como los de su madre, partido de Aragón y Jerusalén-Hungría (1), y partido de Aragón y Sicilia (2), o puede estar presente Sicilia y no Jerusalem. En el primer caso, Aragón puede estar cortado de Navarra. Otra posibilidad es la de unos contracuarteles aragoneses iguales, terciados en pal de Aragón, Sicilia y Jerusalén-Hungría, pudiendo estar el pai de Sicilia cortado de Navarra. Pero tan compleja disposición se simplificó y el resultado fue realmente feliz pues duró hasta Carlos II. Se trata de un medio partido y cortado cuartelado: 1 , cuartelado de Castilla y León; 2 , partido de Aragón y Sicilia; 3 , cuartelado de Austria, Artois, Borgoña y Brabante con escusón de Flandes y Tirol. A veces el partido 2 se encuentra terciado en pal de Aragón, Sicilia y Jerusalén, y puede estar cortado de Sicilia-Navarra. En muchos escudos de Carlos I aparecen las cadenas de Navarra, pero no siempre. Pienso que los criterios son primordialmente propagandísticos. El contracuartel Castilla-León nunca deja de aparecer en ningún escudo del rey-emperador, como base de su poder, aun en los hechos en Centroeuropa. Navarra aparece primordialmente en la heráldica libraria, textos legales o en los emblemas de monumentos hechos en Navarra. Pero está ausente muchas veces en sellos, representaciones artísticas y en alguna moneda. El escudo de Felipe II es igual al de su padre, pero sin el águila bicéfala y con las quinas de Portugal. En algunos escudos de época aparece Navarra, 
particularmente en la heráldica libraria, pero comparativamente con los escudos de Carlos I es más escasa. Con Felipe III, Felipe IV y Carlos II, Navarra aparece escasamente y son las armas de estos reyes semejantes en todo a las de Felipe II. Es en 1646 cuando las Cortes de Pamplona exigen que en los estandartes y pendones reales estén presentes las cadenas de Navarra. En conclusión, los reyes Austrias no tuvieron a Navarra en sus escudos de linaje, pero sí, a veces, en los de dominio. $Y$ en América, salvo algún rarísimo caso en tiempo de Carlos I, las cadenas de Navarra nunca aparecen en las representaciones heráldicas.

Las armas de Felipe $V$ fueron ordenadas por Clairambault, que introdujo la novedad de las tres lises en el centro del escudo y situó el emblema de Flandes y Tirol en la punta. Sorprendentemente, en algunos escudos de Fernando VI sí aparece Navarra en sustitución de Flandes y Tirol. Carlos III hizo una extraña ordenación de las armas reales, colocando en el centro al cuartel Castilla-León, flanqueado por los emblemas de Parma y Toscana, y desterrando una vez más a Navarra del escudo español. Esta disposición fue usada hasta Fernando VII. Con los Borbones, la ausencia de Navarra resulta paradigmática.

Por si fuera poco, en ninguna moneda acuñada por monarcas españoles de la Edad Moderna está presente el emblema de Navarra, a excepción de las labradas en territorio de Navarra y unas pocas de tiempos de Carlos I. ¿A qué se debe esta postergación? Para empezar, hemos dicho que Navarra es Navarra y Castilla, y, por tanto ya está implícitamente representada. En los primeros reyes, con Fernando $V$ y Juana la Loca, si aparece; quizá por el sentido feudalizante de respeto a las realidades políticas y la autoridad del rey sobre sus territorios. Carlos I la conserva, pienso, por motivos propagandísticos; por representar su autoridad amplísima, universal, especialmente ante los propios navarros conquistados, y máximamente si el emblema se presenta en un monumento navarro. Pero con el tiempo la atención se va enfriando. El absolutismo y la llustración son fuertes motivos para no atender factores históricos y rechazar distinciones de grupos. Navarra se incorporó inicialmente a la Corona de Aragón. Ésta debió haber adquirido el título de Corona de Navarra, pues a Navarra debía Aragón su categoría real, concretamente a los acontecimientos ocurridos tras la muerte de Sancho III el Mayor de Navarra. Lo mismo ocurriría con Castilla, cuya realeza se fundamentaba en la sangre real navarra que se transmitió a través de Fernando I, siendo este reino mucho más antiguo que el de Castilla. Pero este formalismo feudal en modo alguno podía imponerse en el siglo XVI, época de maquiavelismos y voluntarismo real. Cuando el rey intruso José Bonaparte diseñó su escudo, plasmó en él las cadenas de Navarra. Paradójicamente, un rey que traía el racionalismo y el liberalismo, la soberanía nacional frente a las 
antiguas monarquías y sus linajes, sacó a la luz, y ya para siempre, la antigua realeza de Navarra, cuya sangre dio vida a los reinos de Castilla y Aragón, y que había sido postergada.

\section{LA EDAD CONTEMPORÁNEA}

Durante la Edad Contemporánea, sólo Fernando VII e Isabel II no incluyeron las cadenas de Navarra en su escudo. Ahora, siguiendo los esquemas establecidos por José Bonaparte, el escudo de España tiende a prescindir de linajes, casas reales o glorias pasadas del imperio español. Simplemente se busca integrar en un emblema todos los espacios geográfico-políticos de una forma simplificada. Los criterios usados son una mezcla de datos geográficos, histórico-políticos, jurídicos y heráldicos.

Por motivos geográficos está León, si bien sus instituciones habían estado fundidas con las de Castilla. Por motivos históricos y jurídico-forales aparece Navarra; no así Vascongadas que tenía fueros pero estaban en Castilla. Tampoco aparece de forma independiente Valencia, reino de la Corona aragonesa como Navarra lo era de la castellana; ni tampoco aparece en solitario Cataluña. $Y$ es que heráldicamente no eran diferenciables del reino de Aragón y política e históricamente estaban en evidente conexión.

Durante los siglos $x \mathrm{Ix}$ y $\mathrm{xx}$ Navarra aparece casi siempre en el escudo de España. No corresponde a la naturaleza de este trabajo señalar exhaustivamente el uso que del mítico escudo de Navarra se hace en la actualidad en el ámbito cultural de Navarra. Basta decir que las cadenas del viejo reino abundan y sobreabundan en todo aquello que quiera tener el cálificativo de "navarro": Arquitectura, escultura, pintura, filatelia, comercio, productos industriales, documentos oficiales, anagramas de todo tipo... Y últimamente, incluso ha salido a la luz la viejísima "Águila negra" de Sancho VII el Fuerte. 
